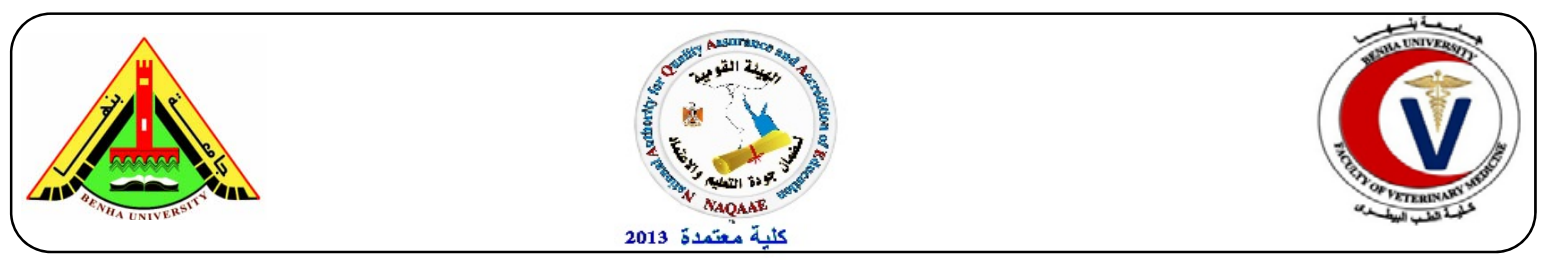

\title{
Studies on parasites that cause diarrhea in calves
}

\author{
${ }^{1}$ Ramadan M. Y., ${ }^{1}$ Khater H. F., ${ }^{2}$ Abd EL Hay A.R., and ${ }^{2}$ Abo Zekry A. M. \\ ${ }^{1}$ Parasitology Department, Fac. Vet. Med. Benha University, ${ }^{2}$ Animal Health Research Institute
}

\begin{abstract}
A B S T R A C T
The aim of present study was detection of parasites cause diarrhea in calves, their seasonal prevalence, and comparative studies on efficacy of chemical drugs (Ivermectin) and natural extracts (Artemisia) against those parasites. 208 fecal samples of diarrheic calves 80 suckling calves ( 41 cow calves +39 buffalo calves) \& 128 weaned calves ( 88 cow calves +40 buffalo calves). The samples were taken From (February2014 to January 2015) from different localities in Munofyia Governorate. The results revealed that the incidence of parasitic diarrhea in suckling calves was $60.1 \%$ and $58.5 \%$ in cow and buffalo respectively. The study indicated that, the weaned diarrhetic cow calves were $68.2 \%$ more than that of buffalo $50 \%$. The detected parasites were Toxocara vitulorum, Trichstrongylus spp., Eimeria spp. and Cryptosporidium spp. The seasonal variation of Toxocara vitulorum was $45.5 \%$ in winter, while the other seasonal variation were $27.3 \%, 18.2 \%$ and $9.09 \%$ in autumn, spring and summer respectively. Trichstrongylus spp. was in spring $50 \%$ and $30 \%$ in autumn. While it was in winter $(20 \%)$ and $0 \%$ in summer. In case of Eimeria spp. it was $13.1 \%, 41.3 \%, 26.9 \%$ and $40 \%$ in winter, spring, summer and autumn respectively. The study, indicated the seasonal variation of Cryptosporidium spp. were $20 \%$, $30 \%, 17.5 \%$ and $32 \%$ in Winter, Spring, Summer and Autumn, respectively. The results of treatment were, the reduction percentage of eggs per gram (EPG) of nematodes was $100 \%$ within first week for Ivermectin, while it was $75 \%$ within second week and was still for Artemisia.
\end{abstract}

Key words: Diarrhea, Calves, Helminthes, protozoa, seasonal variation

(http://www.bvmj.bu.edu.eg)

(BVMJ-29(1): 214-219, 2015)

\section{Introduction}

$\mathrm{C}$ alves are taken much and great importance around the world as sources of good quality meat. It is not uncommon to wean calves and then an experience outbreak of respiratory diseases. Likewise sometimes, the weaned calves will break with diarrhea and this can be more difficult to diagnose the cause. Worms and coccidiosis commonly cause diarrheas in recently weaned calves (John, 2009). In gastro-intestinal nematodes (GIN) group of parasites have a remarkable status as the main pathogens causing severe damage to their hosts. Species of nematodes belonging to group of Trichostrongyloids are the major concern because their blood-sucking feeding habits causing anemia that can be so sever resulting in death of the animals (Macedo Barragan et al., (2009). Ivermectin is one of the widely used ant parasitic agent among cattle (Wjnia et al., 1987). The efficacy of Ivermectin approached $100 \%$ in reduction of egg count in fecal samples of goats. Artemisia is a well know alternative therapeutic with particular application in the treatment of nematodes infection (Taylor and Francis, 2002) .This plant has purgative effects which play role in controlling intestinal worms (Darwich et al; 2009).

Therefore, the aim of present study was detection of parasites cause diarrhea in calves, their seasonal prevalence, and comparative studies on efficacy of chemical drugs (Ivermectin) and natural extracts (Artemisia) against those parasites.

\section{MATERIALS AND METHODS}




\subsection{Fecal samples:}

Fecal samples were collected from 208 calves suffered from diarrhea in different localities in Munofyia Governorate during a period extend from (first February 2014 to the end of January 2015). Fecal samples were collected directly from the rectum of each calf, in plastic sac. The date of collection, age and the name of the owner were recorded. The samples were examined macro and microscopically in the same day of collection, to investigate the internal parasitic cause of diarrhea. The fecal samples were examined according to Soulsby (1988) by the following methods:

Direct fecal smear: A pinhead piece of faces was spread on a microscopic slide and mixed with 1-2 drops of saline solution by the aid of glass stick, then covered by cover slip and examined under light microscope. Floatation method: About $1 \mathrm{ml}$ of sieved mixed sediment fecal specimen with water was diluted by $10-20 \mathrm{ml}$ of saturated salt solution in a test tube and filled to the top. A cover glass was put over the top of the tube so that it was in contact with the liquid. After about 10-20 minutes, the cover glass was gently removed and examined under a low power.

Egg count with the McMaster technique according to Soulsby (1988): Three grams of positive fecal sample were mixed with 45 $\mathrm{ml}$ saturated salt solution shacked and strained. Then a sample was withdrawn by specific pipette and quickly transferred into the counting chambers McMaster slide. The eggs within each ruled area were counted as: The number of eggs/gm (E.P.G)= no of eggs in 2 chamber $/ 2 \times 100$.

Detection of Cryptosporidium oocysts: Fine fecal smears was done, dried in air- fixed with methanol-stained with modified ZiehlNeelson stain- examined with light microscope under oil immersion lens $\mathrm{x}$ 1000 according to Henriksen and Pohlenz., (1981)

\subsection{Treatment}

The objectives of this experiment were to investigate the effectiveness of chemical drugs as Ivermectin against nematodes, which cause diarrhea in calves in compration with the natural extracts such as Artemisia. Fifteen calves suffered from parasitic diarrhea were selected according to parasites and divided into 3 equal groups. The first group ( 5 calves was suffered from parasitic diarrhea due to nematodal causes) was treated with ivermectin, one dose $1 \mathrm{ml} / 50 \mathrm{~kg} \mathrm{~b}$. w. Second group ( 5 calves was suffered parasitic from diarrhea due to Toxocara vitolorum) treated with Artemisia $300 \mathrm{mg} / \mathrm{kg}$ of b.w. twice daily for 5 day. Five calves were used a control group (untreated). The fecal samples were collected in all groups from zero day of treatment until 21 days post treatment.

\section{RESULTS}

\subsection{Incidence of internal parasites in diarrheic suckling calves}

Fecal examination results indicated that the infection among suckling calves was about $60 \%$. The rate of infection in cow calves was $60.1 \%$ while it was $58.5 \%$ in suckling buffalo calves (Table1). The most common helminthic cause was Toxocara vitulorum while Cryptosporidium sp. and Eimeria sp. were the protozoal agents (Table 2). In buffalo suckling calves, $T$. vitulorum infection was highest $17.4 \%$ (4 from 23 number of infection). The results were somewhat decreased in suckling cow calves where the ration of infection was $12 \%$ (3from 24 number of infection). Eimeria Sp. infection was nearly similar rate in both calves spices $32 \%$ and $30.4 \%$ in cow and buffalo suckling calves respectively. On the other hand Cryptosporidium sp. infection was $56 \%$ in cow suckling calves (14from 41 infected) while it was $52.2 \%$ in buffalo suckling calves. From above other results and table (5) the rate of infection in diarrhetic suckling calves was $27.5 \%$ and $32.5 \%$ by helminthes\& Eimeria $s p$. and Cryptosporidium sp. respectively.

\subsection{Incidence of internal parasites in diarrheic weaned Calves:}


The detected parasites species were $T$ .vitulorum, Tichostrongylus spp. as nematode causes while Eimeria and Cryptospordium spp. were the protozoan agents .Each infected calf had at least one parasitic species. Weaned cow calves were suffered more (60 from 88 ) by $(68.2 \%)$ while that of buffalo (20 from 40$)$ by $(50 \%)$ (Table3)

\subsection{Seasonal prevalence of parasites,} which cause diarrhea in calves.

As in table (4) seasonal prevalence of internal parasites among diarrheic calves in comparative manner related to numbers of all examined every season. Toxocara vitulorum: the ratio was in winter $(8.3 \%)$, spring $(4.3 \%)$, summer $(1.9 \%)$ and autumn (6\%). Trichostrongylus spp.: the ratio was in winter $(3.3 \%)$, spring $(10.9 \%)$, summer $(0 \%)$ and autumn (6\%). Eimeria spp.: the ratio was in winter (13.3), spring (41.3\%), summer (26.9\%) and autumn (40\%). Cryptosporidium spp.: the ratio was in winter (13.3\%), spring (26.09\%), summer (13.5\%) and autumn (30\%).

\subsection{Antiparasitic activity of (Ivermectin- Artemisia) against nematodes}

The reduction percent for egg/gram (EPG) of nematodes was $100 \%$ at 1 week for Ivermectin, while it was $75 \%$ at 2 week and egg was still destined (Table 5).

Table (1). Incidence of diarrhea due to parasites among suckling calves (aged 1week-1month).

\begin{tabular}{llll}
\hline Calves spices & No of examined & No of infected & $\%$ \\
\hline Cow calves & 41 & 25 & 60.89 \\
Buffalo calves & 39 & 23 & 58.97 \\
Total & 80 & 48 & 60 \\
\hline
\end{tabular}

Table (2). Incidence of internal parasites recovered in diarrheic suckling Calves.

\begin{tabular}{lcccc}
\hline \multicolumn{1}{c}{ Parasite } & $\begin{array}{l}\text { Toxocara } \\
\text { vitulorum }\end{array}$ & $\begin{array}{l}\text { Eimearia } \\
\text { spp. }\end{array}$ & $\begin{array}{l}\text { Trichostrongylus } \\
\text { spp. }\end{array}$ & $\begin{array}{l}\text { Cryptosporidium } \\
\text { spp. }\end{array}$ \\
Animal & 3 & 8 & 0 & 14 \\
$\begin{array}{l}\text { No. of infected } \\
\text { cow calves }\end{array}$ & 12 & 32 & 0 & 56 \\
$\%$ & 4 & 7 & 0 & 12 \\
$\begin{array}{l}\text { No. of infected } \\
\text { buffalo calves }\end{array}$ & 17 & 30.4 & 0 & 52.2 \\
$\%$ & & & & \\
\hline
\end{tabular}

Table (3). Incidence of parasitic diarrhea among weaned calves aged $>3$ months

\begin{tabular}{llll}
\hline Spices of calves & No. of examined & No. of infected & $\%$ \\
\hline Cow calves & 88 & 60 & 68.2 \\
Buffalo calves & 40 & 20 & 50 \\
Total & 128 & 80 & 62.5 \\
\hline
\end{tabular}


Table (4). Seasonal prevalence of internal parasites among diarrheic calves.

\begin{tabular}{|c|c|c|c|c|c|c|c|c|}
\hline \multirow[t]{2}{*}{ parasites } & \multicolumn{2}{|c|}{$\begin{array}{l}\text { Season \& no. } \\
\text { of examined }\end{array}$} & \multicolumn{2}{|c|}{$\begin{array}{c}\text { Cow calves } \\
\text { No. of infected }\end{array}$} & \multicolumn{2}{|c|}{$\begin{array}{l}\text { Buffalo calves } \\
\text { No. of infected }\end{array}$} & \multirow[t]{2}{*}{ Total } & \multirow[t]{2}{*}{$\%$} \\
\hline & & & suckling & weaned & suckling & weaned & & \\
\hline \multirow[t]{4}{*}{ Toxocara vitulorum } & winter & 60 & 2 & 0 & 2 & 1 & 5 & 8.3 \\
\hline & spring & 46 & 0 & 1 & 1 & 0 & 2 & 4.3 \\
\hline & summer & 52 & 0 & 1 & 0 & 0 & 1 & 1.9 \\
\hline & autumn & 50 & 1 & 0 & 1 & 1 & 3 & 6 \\
\hline \multirow{4}{*}{$\begin{array}{l}\text { Trichostrongylus } \\
\text { spp }\end{array}$} & winter & 60 & 0 & 1 & 0 & 1 & 2 & 3.3 \\
\hline & spring & 46 & 0 & 3 & 0 & 2 & 5 & 10.9 \\
\hline & summer & 52 & 0 & 0 & 0 & 0 & 0 & 0 \\
\hline & autumn & 50 & 0 & 2 & 0 & 1 & 3 & 6 \\
\hline \multirow[t]{4}{*}{ Eimeria spp } & winter & 60 & 2 & 3 & 0 & 3 & 8 & 13.3 \\
\hline & spring & 46 & 2 & 14 & 2 & 1 & 19 & 41.3 \\
\hline & summer & 52 & 1 & 7 & 3 & 3 & 14 & 26.9 \\
\hline & autumn & 50 & 3 & 12 & 2 & 3 & 20 & 40 \\
\hline \multirow{4}{*}{$\begin{array}{l}\text { Cryptosporidium } \\
\text { spp }\end{array}$} & winter & 60 & 2 & 2 & 3 & 1 & 8 & 13.3 \\
\hline & spring & 46 & 4 & 3 & 4 & 1 & 12 & 26.09 \\
\hline & summer & 52 & 3 & 2 & 2 & 0 & 7 & 13.5 \\
\hline & autumn & 50 & 5 & 3 & 3 & 4 & 15 & 30 \\
\hline
\end{tabular}

Table (5). Egg count reduction \% (Ivermectin - Artemisia) comparatively.

\begin{tabular}{llll}
\hline \multicolumn{1}{r}{ Week } & $\begin{array}{l}\text { Reduction } \\
\%\end{array}$ & $\begin{array}{l}\text { Reduction } \\
\%\end{array}$ & $\begin{array}{l}\text { Reduction \% } \\
\text { 3weeks }\end{array}$ \\
& 1 week & 2weeks & \\
\hline Ivermectin & I00 & 100 & 100 \\
Artemisia & 55 & 75 & 75 \\
control & 0 & 0 & $\mathrm{o}$
\end{tabular}

Reduction $\%$ of egg per gram for $(\mathrm{a}$ week $)=$ mean reduced number of that week/total no. without treatment $\times 100$

\section{DISCUSSION}

The present study revealed, that the incidence of parasitic diarrhea, among suckling calves was $60.1 \%$ and $58.5 \%$ in cow and buffalo, suckling respectively. These results were nearly similar to that reported by Sharma, and Busang (2013) who reported that parasitic infection rate in dairy calves was $63.8 \%$, where the rates of infection were $(30.9 \%, 22.20 \%, 10.7 \%)$ due to( Cryptosporidium spp., Eimeria spp., and helminthes respectively). Our study revealed that the detected parasites were: Toxocara vitulorum was highest in suckling buffalo calves (17.4\%) While the latter rate was $12 \%$ in cow suckling calves. In this respect Reberio, et al., ( 2000) reported that Toxocara vitulorum and Eimeria spp. Were the most pathogen in diarrheic calves.

In the present work, Cryptosporidium spp. was detected in $56 \%$ of suckling cow calves, while it was $52.2 \%$ in buffalo. In this respect, Singla et al., (2012) found that prevalence of Cryptosporidium spp. in dairy calves aged 0-30 days was $65.7 \%$, while Sharma, and Busang (2013) found that the prevalence rate in calves less than 3 months was $30.9 \pm 5.6 \%$. This difference may be due to external contamination of udder and contamination of milk utensils in suckling calves (water borne disease). Eimeria spp. in our study, were isolated from both species of suckling calves (cow \& buffalo) 
where the incidence rate was $32 \%$ and $30.4 \%$ respectively. These results were nearly similar to that recorded by Sharma, and Busang (2013) who found that in dairy calves with liquid feces showed 34.8+ 4\% incidence rate of combined helminthes and Eimeria spp. On the other hand Arslan and Sari (2010) reported that the rate was (60$90 \%$ ) in dairy calves in Turkey.

The present study, indicated that the seasonal prevalence of Cryptosporidium spp. were $20 \%, 30 \%, 17.5 \%$ and $32 \%$ in Winter ,Spring , Summer and Autumn, respectively. The highest ratio in autumn $(32 \%)$ then spring $(30 \%)$. While lowers was $(20 \%)$ in winter and $(17.5 \%)$ in summer. This may be attributed to bad condition (cold or hot and dry). Our results were equal to that obtained by other workers, as Taylor et al., (2007). Who found the peaks infection of Cryptosporidium spp. was recorded in autumn and spring Paul et al., (2008) observed that highest prevalence of Cryptosporidium spp. was in worm and humid months among bovine calves. Where the rate of infection was $37.3 \%, 25.6 \%$ and $19.6 \%$ in autumn, summer and winter respectively. The seasonal prevalence of Eimeria spp. in present study was recorded, the ratio was $13.1 \%, 41.3 \%, 26.9 \%$ and $40 \%$ in winter, spring, summer and autumn respectively. In this respect, results of other workers was run parallel to our results as Wahid and Soad (2007) who studied the effect of feeding season on the prevalence of Eimeria spp. in growing buffalo calves in Egypt. They found the ratio of infection was highest in green season (Autumn \& Spring) $94.40 \%$, than dry season (Summer \&Winter) $87.90 \%$. Rahmatullah et al., (2007) reported that prevalence of Eimeria spp. in fecal samples of calves aged 3-4 months was highest in autumn and spring, while it was lower in winter. The ratio was moderate in summer. Also other results in calves less than 2 months in Azerbaijan province reported by Yousef Davoudi et al., (2011). They found that the seasonal prevalence of Eimeria spp. in calves less than 2 months was $13.6 \%, 16 \%, 28 \%$ and $14.4 \%$ in Winter, Autumn, Summer and Spring respectively. Concerning, the seasonal prevalence of Toxocara vitulorum reached its peak in Winter, $(45.5 \%)$ may be due to large number of parturition and /or the presence of third larval stage in colostrums and milk. While the other rates of prevalence were $27.3 \%, 18.2 \%$ and 9.09 $\%$ in autumn, spring and summer respectively. Our results were run parallel to that obtained by Wickramasinghel et al (2009). The latter mentioned that Toxocara vitulorum mainly transmitted through colostrum and milk causing disease (severe anemia, diarrhea, weight loss and anorexia) particularly in buffalo calves between 1-3 months. Concerning, the use Ivermectin and Artemisia in treatment. The results indicated that Ivermectin was the best drug for treatment of intestinal nematodes, and then Artemisia .The reduction percent of fecal egg count per gram (EPG) was 100\% at $4^{\text {th }}$ day post treat by Ivermectin, while it was $55 \%$ at $7^{\text {th }}$ day post treat by Artemisia. our results was agreed with other obtained by Njanja et al., (1987) who reported that the efficacy of Ivermectin approached to $100 \%$ in reduction of egg count in fecal samples of goats. With respect to Artemisia, the present work indicated that the maximum effect was at 7 th day post treatment. The reduction rate was $75 \%$ but eggs were still disseminated in feces. These results of our work agreed with that obtained by Zafar et al., (2004). Who reported Artemisia whole plant process anti thelmintic activity against nematodes.

\section{CONCLUSIONS}

From the results of this study, we conclude that suckling and weaned calves of both cow \& buffalo were infected by internal parasites: Toxocara vitulorum (was highest in suckling calves), Trichostrongylus spp. (were appeared only in weaned calves, but not appeared in suckling one), Cryptosporidium spp. (were highest infection ratio in suckling calves but were declined in weaned), Eimeria spp. (were 
highest in weaned calves, but they were decreased in suckling calves). Ivermectin was suitable drugs against internal nematodes.

\section{ACKNOWLEDGMWNT}

Special Thanks for Center of Excellence in Scientific Research (CESR), fac. of vet. Med. Benha Univ. that funded by management supporting excellence (MSE) and Benha University.

\section{REFRANCES}

Arslan, MO., Sari, B., 2010 Eimeridae (Memelilerde, Coccidiosis) In: Dumanli, N., Karaer, Z., (Eds): Veterinary Protozooloji..Medisan Ltd, Turkiye

Darwich, E., Benziane, Z., Boukir, A., 2009. Chemical composition and insecticidal activity of essential oils of three plants Artemisia spp. Ar. herba- alba, Ar absinthium Ar. pontica (Morocco). EJEAFChe, 8(11):1202- 1211

Fujii, T.U., Del'porto, A., Oliveira, F., 1994. Influência do tratamento antihelminticona eliminação de ovos de Toxocara vitulorum e Strongyloides papillosus, em bezerros búfalos.. Anais. pp. 5.

Henriksen, S.A., J.F., Pohlenz 1981. Staning of Cryptosporidia by modified ZiehlNeelsen technique. Acta Vet. Scand., 22:594-596.

Johan Maas; DVM, MS, 2009' Diarrhea in weaned calves "UCD California cattle's magazine.

Njanja, J.C., Wesecott, R.B., Ruvuna, F., 1987 Comparison of ivermectin and thibenazole for treatment of naturally occurring nematode infections of goats in Kenya Vet. Parasitol, 23:205-209.

Paul, S. D., Chandra, D., Ray, A.K.,Tewari J.R., Roa 2008 Prevalence and molecular characterization of bovine cryptosporidium isolated in India Vet. Parasitol., 153:143-146.

Rahmatullah, A.J., Kamboh A.A., 2007. The incidence of Eimeria species in naturally infected calves. International Journal of Agriculture \& Biology 9(5):741-745.

Riberio, M., Langoni , H., Jerez, J., Leite, D., Ferriera, F., Gennari, S., 2000. Identification of entropathogens from buffalo calves with or without diarrhea in Ribbeira Vally, State of Sao Paulo, Brazil Bar. J. Vet. Res. Anim. Sci. 37(2).

Shama, S., Busang, M., 2013. Prevalence of some gastrointestinal parasites of ruminants in Southern Botswana. Bots. J. Agric. Appl. Sci., 9(2):97-103.

Singh, B.B.R., Sharma, H., Kumar, H.S., Banga, R.S., Aulakh, J.K., Sharma 2006. Prevalence of cryptosporidium pavarum infection in Punjab (India) and its association with diarrhea in neonatal dairy calves Vet. Parasitol. ,. 140:162 165.

Soulsby, J., 1988. Helminthes of domesticated animals. English book society/baillieretindall

Taylor, M.A., Coop, R.L., Wall, R.L., 2007. Veterinary Parasitology. Third Edn. Blackwell Publishing.

Wahid M.A., Soad E., Hassan, 2007. Applied studies on coccidiosis in growing buffalo calves in Egypt " World Journal of Zoology 2(2):40-48.

Wickramasinghe, S., Yatawara,R. P.V., Rajapaks Agatsuma, 2009. Toxocara vitulorum Mitochondrial gene content arrangement and composition compared with other Toxocara species.Mol. Biochem. Parasitol 166:89-92

Yousef Davoudi, Yagoob Garedaghi, Freydoun Nour mohammad zadeh, Zahra Eftekhari, Saied Safarmashaei, 2011. Advances in Environmental Biology, 5(7):1563-1565

Zafar Iqbal, Muhammad Lateef Ashraf, Adual Jabbar, 2004. Anthelmintic activity Ar. brevfolia in sheep. Journal of Ethno pharmacology, 93(2-3):265-8. 